Acta Theriologica 45 (4): 491-505, 2000.

PL ISSN 0001-7051

\title{
Architecture of Ctenomys mendocinus (Rodentia) burrows from two habitats differing in abundance and complexity of vegetation
}

\author{
María I. ROSI, Mónica I. CONA, Fernando VIDELA, \\ Silvia PUIG, and Virgilio G. ROIG
}

\begin{abstract}
Rosi M. I., Cona M. I., Videla F., Puig S. and Roig V. G. 2000. Architecture of Ctenomys mendocinus (Rodentia) burrows from two habitats differing in abundance and complexity of vegetation. Acta Theriologica 45: 491-505.

Burrow systems of the fossorial rodent Ctenomys mendocinus Philippi, 1869 were studied in the Andean Precordillera. These burrows were linear, with laterals and branches forked off the main tunnel. Their size and architecture did not differ between sexes. Burrows showed a constant heading along the main tunnel, with a mean directional angle close to $0^{\circ}$. Most forks of the main tunnel were originated more than expected at plants, indicating a change of search pattern where plants were encountered. This behaviour suggests a tactic consistent with area-restricted search. These systems were compared with others of the same species located in a habitat with higher cover and structural complexity of vegetation, at the Mendoza Piedmont. Female burrows were larger and male burrows more bifurcated in the Precordillera. These burrows were more complex than those from the Piedmont, owing to the presence of secondary tunnels. The mean directional angle close to $0^{\circ}$, orthogonal branches and angles of ascent of laterals close to $40^{\circ}$ were attributes shared by the systems of both habitats. $C$. mendocinus maintains a basic search pattern as an optimal forager, and increases the systems size and complexity probably as an adaptive strategy to optimize the foraging efficiency and minimize the predation risk.

Unidad de Ecología Animal, Instituto Argentino de Investigaciones de Zonas Aridas (IADIZA-CONICET), CC. 507, 5500, Mendoza, Argentina, e-mail: mrosi@lab.cricyt.edu.ar

Key words: Ctenomys, fossorial rodents, burrows, plant communities
\end{abstract}

\section{Introduction}

Subterranean mammals construct burrows and modify them throughout their life, in response to changes in environmental factors and physiological requirements (Reichman and Smith 1990). Structural features of burrow systems have been studied in several subterranean mammal species (citations in Hickman 1990), but little is known about variation in size and architecture of systems located in environments with different food abundance. Reichman et al. (1982) compared burrows of Thomomys bottae in two habitats with vegetation homogeneously dispersed (O. J. Reichman, pers. comm. in Cameron et al. 1988), and found systems more linear, longer and with a larger number of branches at the site of lower 
production. In habitats with clumped vegetation, Heth (1989) reported burrows of Spalax ehrenbergi longer but less branched where the plant productivity was lower. In contrast, Andersen (1988) and Cameron et al. (1988) did not find that the environmental quality affected the architecture and size of burrows constructed by pocket gophers.

Ctenomys mendocinus Philippi, 1869, a South American fossorial rodent, inhabits environments in the Piedmont and the Andean Precordillera of Mendoza (Argentina). Rosi et al. (1996) reported extended bifurcated linear systems for this species in a Piedmont habitat (1125 m a.s.l.), a geometric configuration similar to that documented for other subterranean mammals (Pearson 1959, Reichman et al. 1982, Andersen 1988, Heth 1989, Antinuchi and Busch 1992). Populations of the same species located at the Precordillera at $3000 \mathrm{~m}$ a.s.l. (Puig et al. 1992, Rosi et al. 1992) have a lower diversity and plant cover (Ambrosetti et al. 1986) than reported for the Piedmont (Roig 1976).

This paper describes structural features of $C$. mendocinus burrow systems and their relationship with vegetation in a Precordillera environment. Size and structure of these systems were compared with those analyzed by Rosi et al. (1996) in the Andean Piedmont of Mendoza, in order to determine system differences between two environments differing in the abundance and complexity of vegetation.

\section{Study area}

Studies were conducted in Paramillos of Uspallata (Mendoza, Argentina, $32^{\circ} 29^{\prime} \mathrm{S}, 69^{\circ} 8^{\prime} \mathrm{W}$ ), an area of high plateaux and valleys located in the Andean Precordillera (3000 m a.s.l.). The climate is arid, with a lengthy winter period (May to November), snowfall occurring between July and September, and mean temperatures below $0^{\circ} \mathrm{C}$ between May and October (Capitanelli 1972). Such low temperatures account for seasonal ground freezing (Corte 1986). Soils are relatively compact, with a predominance of lithosols composed by coarse sands and rocks fractured by cryogenic phenomena. The textural matrix is characterized by fine sand $(85 \%)$, clay $(8 \%)$ and silt $(6 \%)$. Grass communities of Stipa spp. are dominant, alternating with low shrubs (Ambrosetti et al. 1986). Use of the nearest-neighbour distance method (Clark and Evans 1954) indicated the vegetation showed a clustered spatial arrangement $(n=160, R=0.35, C=-15.84, p<0.0001)$.

\section{Material and methods}

Burrow systems of 12 sexually active adult animals ( 6 males, 6 females) were excavated, measured and mapped in spring and summer (November 1995 and February 1996). All open tunnels were excavated in each burrow system as were all tunnels refilled with loose or slightly compacted soil. Length, depth, diameter and directionality of tunnel sections and chambers were measured for every system. Simultaneously, the location of every plant species growing over the burrow was recorded, and their percent cover estimated. Burrow structural features were described with the same terminology used for other subterranean mammals (Vleck 1981, Reichman et al.1982, Andersen 1988), and for other population of C. mendocinus (Rosi et al. 1996). Each tunnel section determined by a crange in heading was called a segment. The longest axis of the system was considered as the main tunnel (Fig. 1). Branching tunnels forking off the main axis were classified as laterals (straight tunnels that never branch) and branches (tunnels made up of at least one segment and one lateral). Tunnels 
classified as laterals included those reaching the surface and also those ending in a "cul-de-sac" (hereafter referred to as blind laterals). In most systems the main tunnel forked into two tunnels that met further up to again form a single tunnel. On such occasions, the tunnel showing the smallest angular deviation was regarded as the main tunnel, and the other as a secondary tunnel.

Deviation angles (directional angles) between consecutive segments of the main tunnel were measured beginning arbitrarily from one of the system ends. Left-ward (negative) or right-ward (positive) deviations were considered for these directional angles. The branch angle was measured as the smallest angle between the initial segment of every branch and the main tunnel. The angle of ascent (Vleck 1981) was estimated only for those laterals that reached the surface.

Area, perimeter and linearity of the home range were determined by every system, following the accepted criterion for home range of subterranean mammals, as coincident with territory, and restricted to the burrow system (Ingles 1952, Howard and Childs 1959, Nevo 1979). In order to determine the area actually defended by the animal an irregular polygon around each burrow was constructed by joining the ends of all laterals. For every angle between two segments from which no lateral came off, the bisector of the convex angle was drawn. The length of an estimated lateral was projected on this bisector. This lateral was obtained by averaging the perpendicular distances between the end of every actual lateral and the originating tunnel segment (Rosi et al. 1996). Area and perimeter of each polygon were measured with Tecktronix 4958 digitizer and the INCYTH-CRA's programme for calculating areas. Linearity of a burrow system was determined based on criteria of Reichman et al. (1982).

Plant species cover was measured along $30-\mathrm{m}$ transects, located on sites showing no evidence of Ctenomys' activities. The 20 transects traversed in each habitat allowed a good estimation of plant richness, according to Roig (1976) for Precordillera, and Ambrosetti et al. (1986) for Piedmont. All transects were carried out at the same time as burrow excavations. Plant species were grouped in 6 categories: grasses, forbs, succulents, low shrubs (lower than $1 \mathrm{~m}$ ), high shrubs (over $1 \mathrm{~m}$ high), and trees.

Numerical results are given as $\bar{x} \pm \mathrm{SD} ; n$ is only indicated in cases where it differed from the number of individuals. Statistical analyses were made to compare all metric and angular variables between male and female burrows in the Precordillera. Comparisons between habitats (Precordillera vs Piedmont) were drawn separately for each sex using the raw data. All metric variables were tested for normality and variance homogeneity. The Student's $t$-test was used when these criteria were met; otherwise the Mann-Whitney $U$-test was applied. Angular variables were analyzed by circular statistics (Zar 1984). An approximate testing procedure for differences between two proportions $(Z)$ was used as described by Zar (1984). Pearson's product-moment correlation coefficient $r_{\mathrm{P}}$ was used for relationships between different metric variables. The Chi-Square test was used to determine whether initiation points of branches and laterals forking off of the main tunnel were associated with plant localities.

Absolute plant cover was estimated for the total species presented, and for each plant category. Differences in plant cover between habitats were assessed by Mann-Whitney $U$-test, and differences in diversity by ANOVA. Plant diversity was estimated through the Shannon-Wiener index $\left(H^{\prime}\right)$ and Kulczynski's coefficient $\left(S_{k}\right.$, Oosting 1956) was used to estimated similarities.

\section{Results}

\section{Size and structural features of burrow systems in the Precordillera}

A sexually active animal inhabited every excavated burrow. Both mean body weight (males: $180.3 \pm 16.3 \mathrm{~g}$, females: $147.8 \pm 7.7 \mathrm{~g}$ ), and total body length (males: $250.5 \pm 9.5 \mathrm{~mm}$, females: $235.2 \pm 4.8 \mathrm{~mm})$ were significantly higher in males $(t=$ $4.42, p=0.001$ and $t=3.55, p=0.005$, respectively). The sexes did not differ significantly in relative age which was estimated from dry lens weight (males: 29.6 $\pm 7.4 \mathrm{mg}$, females: $29.9 \pm 5.3 \mathrm{mg} ; t=0.076, p=0.94$ ). 


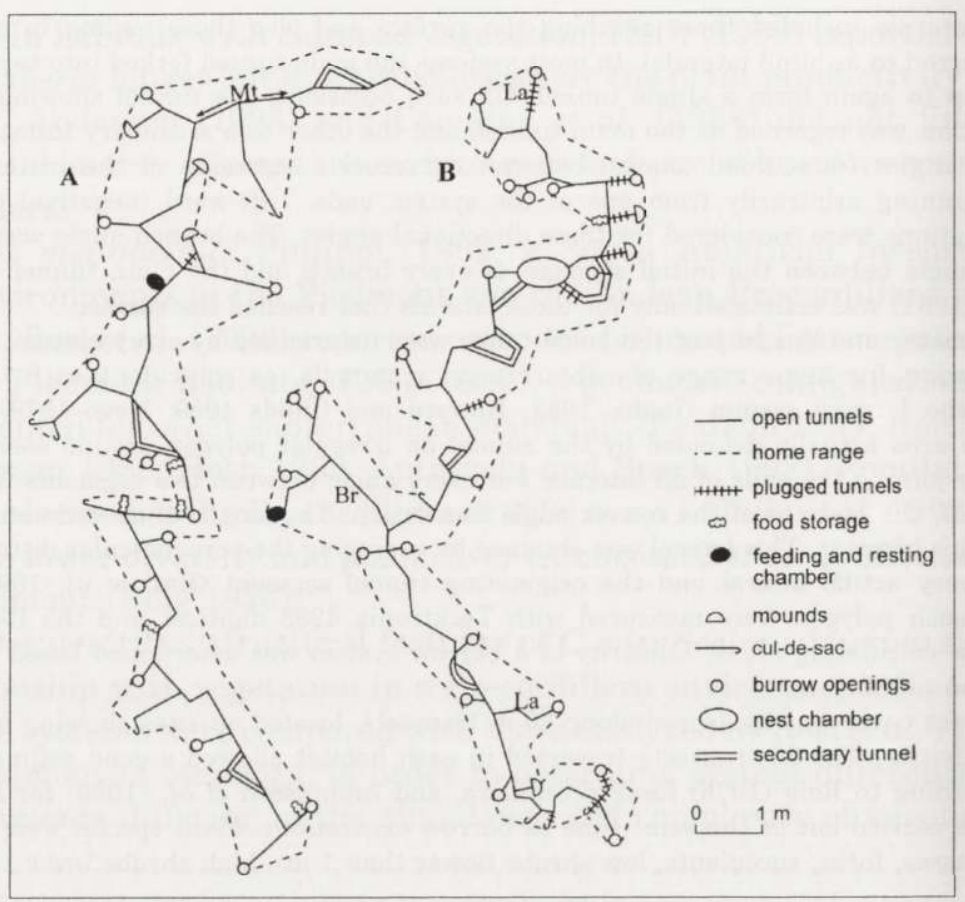

Fig. 1. Schematic representations of excavated burrow systems of Ctenomys mendocinus from the Mendoza Precordillera (Argentina). Burrows of adult male (A) and female (B). Mt - main tunnel, Br branch, $\mathrm{La}$ - lateral.

All burrows consisted of a main tunnel from which branches and laterals forked off (Fig. 1). Proportions of the total system occupied by the main tunnel (males: $42 \%$, females: $46 \% ; Z=-1.19, p=0.2$ ), branches (males: $22.2 \%$, females: $17.5 \%$; $Z=1.18, p=0.2$ ), and laterals (males: $26.6 \%$, females: $29.2 \% ; Z=-0.61, p>0.5$ ) did not differ between sexes.

Total length of the system (23.1 to $68.3 \mathrm{~m}$ ), was similar for males and females (Table 1). It was significantly correlated with the main tunnel length $\left(r_{\mathrm{P}}=0.88\right.$, $\mathrm{df}=11, p<0.001)$, the branches length $\left(r_{\mathrm{P}}=0.67 \mathrm{df}=11, p<0.02\right)$ and the number of laterals $\left(r_{\mathrm{P}}=0.80, \mathrm{df}=11, p<0.002\right)$. It was not correlated with the mean length of branches and laterals $\left(r_{\mathrm{P}}=-0.08 \mathrm{df}=11, p>0.50\right.$ and $r_{\mathrm{P}}=-0.48$, $\mathrm{df}=11, p>0.05$, respectively). Correlations between total length of the system and body weight were not significant for males $\left(r_{\mathrm{P}}=-0.37 \mathrm{df}=5, p>0.20\right)$ and females $\left(r_{\mathrm{P}}=0.41, \mathrm{df}=5, p>0.20\right)$.

Main tunnel sections extending between consecutive laterals (hereafter "interforks") included from 1 to 7 segments. Number, depth and mean length of segments showed no significant differences between sexes (Table 1). Interfork distances showed great variability, ranging from 0.20 to $5.49 \mathrm{~m}$ (avg. $1.29 \pm 1.03 \mathrm{~m}, n=175$ ). 
Table 1. Metric variables $(\bar{x} \pm \mathrm{SD})$ of Ctenomys mendocinus burrow systems from Precordillera and Piedmont, compared using the Mann Whitney $U$-test and the Student's $t$-test. The Piedmont data come from Rosi et al. (1996). ${ }^{a}$ Means of $2^{\circ}$ estimated from six means of $1^{\circ}$ for each sex, ${ }^{b}$ indicates variable expressed per meter of tunnel, ${ }^{*} p>0.05$ in all cases.

\begin{tabular}{|c|c|c|c|c|c|c|c|}
\hline \multirow{3}{*}{ Variable } & \multicolumn{4}{|c|}{ Precordillera } & \multirow{3}{*}{$\begin{array}{l}\text { Value of the } \\
\text { statistic* }\end{array}$} & \multicolumn{2}{|c|}{ Piedmont } \\
\hline & \multicolumn{2}{|r|}{ Males } & \multicolumn{2}{|c|}{ Females } & & \multirow{2}{*}{$\frac{\text { Males }}{\bar{x}}$} & \multirow{2}{*}{$\frac{\text { Females }}{\bar{x}}$} \\
\hline & $n$ & $\bar{x} \pm \mathrm{SD}$ & $n$ & $\bar{x} \pm \mathrm{SD}$ & & & \\
\hline \multicolumn{8}{|c|}{ Main tunnel } \\
\hline Total length (m) & 6 & $19.9 \pm 7.9$ & 6 & $19.1 \pm 5.1$ & $t=0.19$ & 32.3 & 13.5 \\
\hline Mean depth $(\mathrm{m})^{\mathrm{a}}$ & 110 & $0.2 \pm 0.0$ & 112 & $0.3 \pm 0.0$ & $t=-0.96$ & 0.3 & 0.3 \\
\hline Number of segment & 6 & $45.3 \pm 20.1$ & 6 & $39.3 \pm 6.3$ & $U=21.5$ & 41.6 & 26.5 \\
\hline Mean segment length $(\mathrm{m})^{\mathrm{a}}$ & 272 & $0.5 \pm 0.1$ & 236 & $0.5 \pm 0.1$ & $t=-0.39$ & 0.7 & 0.5 \\
\hline \multicolumn{8}{|c|}{ Branches } \\
\hline Total length for system (m) & 6 & $10.7 \pm 5.4$ & 6 & $7.3 \pm 3.4$ & $t=1.34$ & 8.9 & 3.6 \\
\hline Mean length $(\mathrm{m})^{\mathrm{a}}$ & 46 & $1.5 \pm 0.3$ & 36 & $1.3 \pm 0.7$ & $t=0.59$ & 2.3 & 1.5 \\
\hline Number of branch & 6 & $7.7 \pm 4.6$ & 6 & $6.0 \pm 2.4$ & $t=0.80$ & 4.0 & 2.5 \\
\hline Number of branch ${ }^{b}$ & 6 & $0.3 \pm 0.2$ & 6 & $0.3 \pm 0.2$ & $t=0.47$ & 0.1 & 0.2 \\
\hline \multicolumn{8}{|c|}{ Laterals } \\
\hline Total length for system (m) & 6 & $12.9 \pm 4.3$ & 6 & $12.1 \pm 2.4$ & $t=0.37$ & 9.6 & 5.3 \\
\hline Mean length $(\mathrm{m})^{\mathrm{a}}$ & 196 & $0.4 \pm 0.1$ & 183 & $0.4 \pm 0.1$ & $t=0.48$ & 0.4 & 0.3 \\
\hline Number of laterals & 6 & $32.7 \pm 15.0$ & 6 & $30.5 \pm 5.6$ & $U=21.0$ & 22.8 & 15.8 \\
\hline Number of lateral $^{b}$ & 6 & $1.0 \pm 0.2$ & 6 & $1.1 \pm 0.1$ & $t=-1.18$ & 0.6 & 1.0 \\
\hline Number of mounds ${ }^{b}$ & 6 & $8.0 \pm 5.6$ & 6 & $5.0 \pm 1.3$ & $t=0.93$ & 7.6 & 4.8 \\
\hline Total length of system (m) & 6 & $48.3 \pm 18.2$ & 6 & $41.5 \pm 9.4$ & $t=0.81$ & 50.5 & 22.4 \\
\hline Area $\left(\mathrm{m}^{2}\right)$ & 6 & $23.7 \pm 7.4$ & 6 & $21.7 \pm 6.1$ & $t=0.51$ & 43.1 & 11.9 \\
\hline Perimeter (m) & 6 & $51.3 \pm 19.8$ & 6 & $46.1 \pm 11.0$ & $t=0.56$ & 74.4 & 31.7 \\
\hline Linearity & 6 & $2.9 \pm 0.7$ & 6 & $2.8 \pm 0.3$ & $t=0.42$ & 3.3 & 2.6 \\
\hline
\end{tabular}

The total length of the main tunnel was significantly correlated with the number of segments $\left(r_{\mathrm{P}}=0.82, \mathrm{df}=10, p<0.002\right)$ and of interforks $\left(r_{\mathrm{P}}=0.82, \mathrm{df}=11, p<\right.$ $0.001)$. The correlation with mean length of segments was not significant $\left(r_{\mathrm{P}}=\right.$ $0.44, \mathrm{df}=10, p>0.10$ ). The directional angles of consecutive segments of the main tunnel ranged from -120 to $144^{\circ}(n=512)$. In most systems, rightward (positive) and leftward (negative) deviations of segments were similar in both number and mean value (Table 2). By using a two-tailed runs test (Zar 1984) a random sequence of construction of positive and negative segments was found in every system. Mean directional angles of each system did not significantly differ from $0^{\circ}$ (Table 2), and showed no significant differences between or within sexes (Table 3).

The number of branches in a system ranged from 2 to 13 . Secondary branches were found in 8 systems. Mean values of metric variables in branches were similar 
Table 2. Directional angles of each main tunnel of Ctenomys mendocinus burrow excavated in Precordillera: number of angles $(n)$, mean values in degrees $(\bar{x})$ and angular deviations (S), considering all angles $(t)$, or those positive $(p)$ and negative $(n)$ separately. The random sequence of segments construction was evaluated by the two-tailed runs test ( $u$ - number of runs), and the main tunnel deviation from $0^{\circ}$ by the one-sample test for mean angles ( $\mathrm{d}$ - confidence interval at $99 \%, \mathrm{r}-$ length of mean vector), according to Zar (1984). * The critical values for the two-tailed runs test ranged between $p=0.10$ and $p>0.50$.

\begin{tabular}{|c|c|c|c|c|c|c|c|c|c|c|}
\hline \multirow{3}{*}{$\begin{array}{l}\text { Individual } \\
\text { number }\end{array}$} & \multirow{2}{*}{\multicolumn{3}{|c|}{ Mean directional angles }} & \multirow{2}{*}{\multicolumn{2}{|c|}{$\begin{array}{l}\text { Estimators of the } \\
\text { one-sample test }\end{array}$}} & \multicolumn{4}{|c|}{$\begin{array}{l}\text { Estimators of the two-tailed } \\
\text { runs test }\end{array}$} & \multirow[b]{3}{*}{$u^{*}$} \\
\hline & & & & & & \multicolumn{2}{|c|}{ Positive angles } & \multicolumn{2}{|c|}{ Negative angles } & \\
\hline & $n_{\mathrm{t}}$ & $\bar{x}_{\mathrm{t}}$ & $\mathrm{S}_{\mathrm{t}}$ & d & $\mathrm{r}$ & $n_{\mathrm{p}}$ & $\bar{x}_{\mathrm{p}}$ & $n_{\mathrm{n}}$ & $\bar{x}_{\mathrm{n}}$ & \\
\hline \multicolumn{11}{|l|}{ Males } \\
\hline 311 & 30 & 7 & 50.3 & 30 & 0.61 & 17 & 48 & 12 & -54 & 20 \\
\hline 314 & 16 & 13 & 49.3 & 44 & 0.63 & 8 & 56 & 6 & -41 & 7 \\
\hline 319 & 78 & -1 & 53.0 & 14 & 0.57 & 34 & 57 & 37 & -51 & 45 \\
\hline 323 & 39 & 12 & 54.0 & 29 & 0.56 & 23 & 50 & 14 & -64 & 23 \\
\hline 324 & 51 & -3 & 54.2 & 26 & 0.55 & 22 & 54 & 23 & -61 & 28 \\
\hline 328 & 69 & 3 & 46.4 & 19 & 0.67 & 38 & 39 & 27 & -52 & 40 \\
\hline \multicolumn{11}{|l|}{ Females } \\
\hline 312 & 30 & 9 & 50.0 & 30 & 0.62 & 15 & 53 & 12 & -48 & 18 \\
\hline 313 & 36 & 1 & 51.6 & 28 & 0.59 & 19 & 44 & 16 & -55 & 21 \\
\hline 317 & 33 & -4 & 51.9 & 29 & 0.59 & 10 & 65 & 13 & -60 & 7 \\
\hline 318 & 45 & -4 & 47.9 & 25 & 0.65 & 19 & 45 & 21 & -48 & 25 \\
\hline 320 & 41 & -1 & 50.6 & 25 & 0.61 & 20 & 47 & 19 & -53 & 21 \\
\hline 326 & 44 & 9 & 51.7 & 25 & 0.59 & 21 & 57 & 18 & -50 & 11 \\
\hline
\end{tabular}

between sexes (Table 1). Branch angles did not differ between systems of the same sex or between sexes (Table 3). Confidence intervals of mean branch angles for males $\left(87-98^{\circ}\right)$ and females $\left(79-94^{\circ}\right)$ showed that mean values did not differ significantly from $90^{\circ}$ (length of mean vector $\mathrm{r}=0.95$ for females, and $\mathrm{r}=0.91$ for males; one sample test for mean angles with $p=0.01$, Zar 1984). The highest frequencies of branch angles ranged between $90^{\circ}$ and $110^{\circ}$ (Fig. 2).

Number of laterals ranged from 14 to 47 per system. Mean values of variables were similar between sexes (Table 1$)$. All laterals $(n=379)$ reached the surface $(64 \%)$, or ended in "cul-de-sac" $(36 \%)$. Only $33 \%$ of the former ended in a soil mound and the rest ended in a hole plugged. Mean number of mounds per system did not differ between sexes. Angles of ascent of laterals did not differ between or within sexes (Table 3); their highest frequencies ranged from 30 to $50^{\circ}$ (Fig. 2).

Most of the excavated systems ( 10 of 12 ) showed 1 to 4 secondary tunnels, $35 \%$ of them with branches and/or laterals. Length of secondary tunnels varied between 0.26 and $3.35 \mathrm{~m}$. All systems showed sections of the main tunnel (8\%), branches 
Table 3. Angular variables ( $\bar{x}-$ mean and $\mathrm{S}-$ angular deviations in degrees) of burrow systems of Ctenomys mendocinus, where $n$ is the number of values and (k) the number of means used in the estimation of a $2^{\circ}$ mean. The $\chi^{2}$ contingency test and the Watson's $U^{2}$-test were used for comparisons within each sex and between sexes, respectively.

\begin{tabular}{|c|c|c|c|c|c|c|c|}
\hline \multicolumn{4}{|c|}{ Comparisons between sexes in Precordillera } & \multicolumn{4}{|c|}{ Comparisons between habitats including both sexes } \\
\hline Estimators & $\begin{array}{l}\text { Female } \\
\text { burrows }\end{array}$ & $\begin{array}{c}\text { Male } \\
\text { burrows }\end{array}$ & $\begin{array}{l}\text { Value of the } \\
\text { statistic }\end{array}$ & Estimators & $\begin{array}{c}\text { Precordillera } \\
\text { burrows }\end{array}$ & $\begin{array}{l}\text { Piedmont } \\
\text { burrows }\end{array}$ & $\begin{array}{l}\text { Value of the } \\
\text { statistic }\end{array}$ \\
\hline \multicolumn{8}{|c|}{ Directional angles } \\
\hline $\begin{array}{l}\bar{x}(\mathrm{~S}) \\
n(\mathrm{k}) \\
\chi^{2}(\mathrm{df})\end{array}$ & $\begin{array}{l}1.4(50.8) \\
229(6) \\
27.3(40) \\
p>0.90\end{array}$ & $\begin{array}{l}3.4(51.8) \\
267(5) \\
45.2(32) \\
p>0.05\end{array}$ & $\begin{array}{l}U^{2}=0.07 \\
\mathrm{df}=6,5 \\
p>0.50\end{array}$ & $\begin{array}{l}\bar{x}(\mathrm{~S}) \\
n(\mathrm{k})\end{array}$ & $\begin{array}{l}2.3(51.3) \\
496(12)\end{array}$ & $\begin{array}{c}-0.2(47.3) \\
381(12)\end{array}$ & $\begin{array}{l}U^{2}=0.16 \\
\mathrm{df}=11,12 \\
p>0.05\end{array}$ \\
\hline \multicolumn{8}{|c|}{ Branch angles } \\
\hline $\begin{array}{l}\bar{x}(\mathrm{~S}) \\
n \\
\chi^{2}(\mathrm{df})\end{array}$ & $\begin{array}{l}86.9(17.4) \\
39 \\
19.1(20) \\
p>0.50\end{array}$ & $\begin{array}{l}87.1(24.5) \\
40 \\
32.4(30) \\
p>0.25\end{array}$ & $\begin{array}{l}U^{2}=0.08 \\
\mathrm{df}=39,40 \\
p>0.50\end{array}$ & $\begin{array}{l}\bar{x}(\mathbf{S}) \\
n\end{array}$ & $\begin{array}{l}87.0(21.3) \\
79\end{array}$ & $\begin{array}{l}86.7(19.3) \\
34\end{array}$ & $\begin{array}{l}\chi^{2}=1.36 \\
\mathrm{df}=3 \\
p>0.50\end{array}$ \\
\hline \multicolumn{8}{|c|}{ Angles of ascent for laterals } \\
\hline $\begin{array}{l}\bar{x}(\mathrm{~S}) \\
n(\mathrm{k}) \\
\chi^{2}(\mathrm{df})\end{array}$ & $\begin{array}{l}39.9(15.0) \\
66(5) \\
17.3(12) \\
p>0.10\end{array}$ & $\begin{array}{l}36.3(15.1) \\
72(6) \\
15.6(15) \\
p>0.25\end{array}$ & $\begin{array}{l}U^{2}=0.23 \\
\mathrm{df}=5,6 \\
p>0.05\end{array}$ & $\begin{array}{l}\bar{x}(\mathrm{~S}) \\
n(\mathrm{k})\end{array}$ & $\begin{array}{l}37.9(15.2) \\
138(12)\end{array}$ & $\begin{array}{l}36.2(17.0) \\
70(12)\end{array}$ & $\begin{aligned} U^{2} & =0.18 \\
\mathrm{df} & =11,11 \\
p & >0.05\end{aligned}$ \\
\hline
\end{tabular}

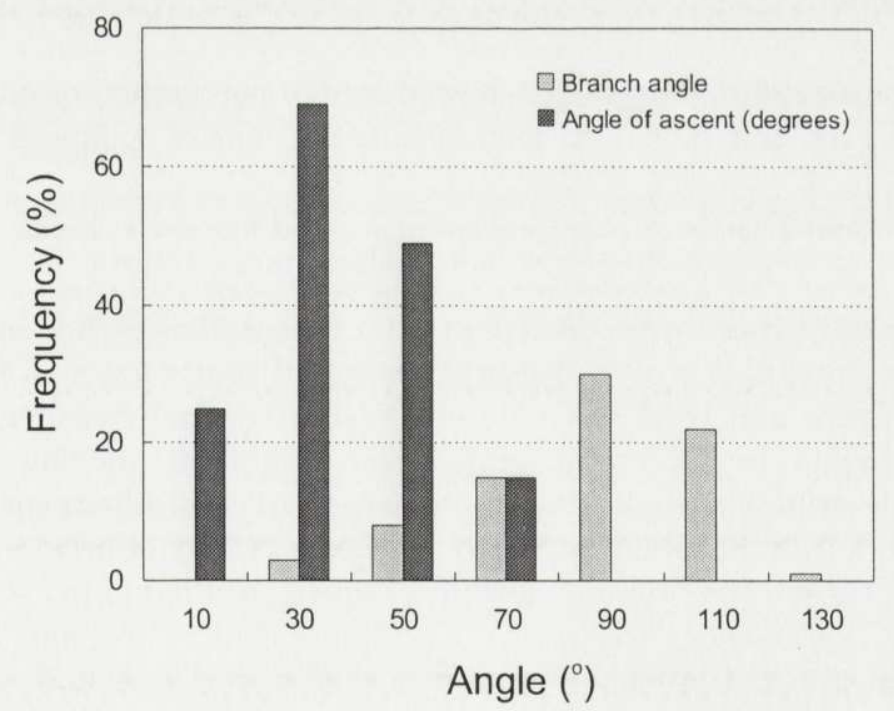

Fig. 2. Frequency distributions of burrow branch angles $(n=79)$ and angles of ascent of laterals $(n=$ 158) measured in the Ctenomys mendocinus burrow systems from Precordillera. 
(16\%) and laterals (27\%) plugged with soil. Total proportion of tunnels plugged was $16 \%$ and $12 \%$ for males and females, respectively.

Areas and perimeters of home ranges ranged between 12 and $33 \mathrm{~m}^{2}$, and between 27 and $71 \mathrm{~m}^{2}$, respectively. Mean values did not significantly differ between sexes (Table 1). Home range perimeters $(48.7 \pm 15.5 \mathrm{~m}, n=12)$ were significantly higher $(U=144 \mathrm{df}=12, p<0.001)$ than the expected values for circular home ranges with identical areas $(16.7 \pm 2.5 \mathrm{~m}, n=12)$. Linearity values were higher than 1.9 and did not differ between sexes.

\section{Relationships between vegetation and foraging tunnels at the Precordillera}

An average of twenty percent of the main tunnel crossed vegetation patches. The origin of $50 \%$ of secondary tunnels $(n=26)$ and branches derived from the main tunnel $(n=82)$ were located at a plant. High percentages of laterals that ended in a hole plugged ( $72 \%$ of $n=104$ ) and blind laterals ( $58 \%$ of $n=71$ ) forking off the main tunnel were associated with plant localities. The numbers of branches $\left(\chi^{2}=48.6, p<0.001\right)$ and laterals that ended in a plugged hole $\left(\chi^{2}=183.4, p<\right.$ $0.001)$ or blind laterals $\left(\chi^{2}=66.2, p<0.001\right)$, whose origin coincided with a plant, were significantly higher than the expected values according to the plant cover over the main tunnel.

Most burrows ( $n=11$ ) had 2 to 8 storage chambers, mainly filled by grasses of Stipa genus. Total dry weight of stored plant material per system ranged for 5 females from 51.5 to $927.2 \mathrm{~g}$, while the remaining showed a notoriously heavier storage ( $4314.7 \mathrm{~g})$. One male system presented no storage; the stored plant material for the other 5 systems ranged from 91.4 to $442.4 \mathrm{~g}$. The greatest proportion for female and male systems ( $77 \%$ and $71 \%$, respectively) proceeded from the nest chamber.

The area surrounding 9 systems showed a high percentage of bare soil (93\%) with numerous inactive holes, old mounds and sections of collapsed tunnels.

\section{Comparisons of plant communities and burrow systems between Piedmont and Precordillera habitats}

Nineteen plant genera were detected in the Precordillera study area and 29 in the Piedmont. Total plant cover (Table 4) was significantly lower in Precordillera, where high shrubs and trees were absent. Forb cover and succulent cover were significantly higher in Piedmont, while cover of grasses and low shrubs were similar in both sites. The highest absolute cover in Precordillera corresponded to grasses (Table 4), almost all belonging to Stipa spp. (15\%), followed by low shrubs. High shrubs raised the highest absolute cover in Piedmont, where Larrea divaricata (36\%) prevails. Grass cover was also important; Stipa spp. (20\%) was the most abundant grass. A low plant similarity coefficient $\left(S_{k}=0.27\right)$ was obtained between both environments, while the plant diversity $\left(H^{\prime}\right)$ was significantly higher in the Piedmont. 
Table 4. Comparisons of plant cover (with Mann Whitney $U$-test) and vegetal diversity (with ANOVA) between Precordillera and Piedmont.

\begin{tabular}{lcccc}
\hline Variable & Precordillera & Piedmont & Value of the statistic & Significance level \\
\hline \multicolumn{5}{c}{ Absolute plant cover $(\%)$} \\
Grasses & 15.15 & 20.57 & $U=203$ & $p>0.05$ \\
Forbs & 0.21 & 1.23 & $U=258$ & $p<0.001$ \\
Succulents & 0.28 & 10.32 & $U=263$ & $p<0.001$ \\
Low shrubs & 10.50 & 18.85 & $U=207$ & $p>0.05$ \\
High shrubs & - & 44.42 & - & - \\
Trees & - & 7.25 & - & - \\
Total cover & 24.49 & 68.23 & $U=297$ & \\
& & Plant diversity & & $p<0.001$ \\
$H^{\prime}$ & $0.26 \pm 0.02$ & $0.75 \pm 0.03$ & $F=182.7$ & $p<0.001$ \\
\hline
\end{tabular}

Males and females whose burrows were analyzed at the Precordillera did not significantly differ in body weights $(U=22, p>0.20$ and $t=1.35, p=0.20$, respectively) from those of the Piedmont (males: $19 \pm 52.7 \mathrm{~g}, n=6$; females: $141 \pm$ $10.8 \mathrm{~g}, n=6$ ). Main tunnel length constituted a significantly lower proportion of the burrow system $(Z=-6.95, p<0.001)$ at the Precordillera $(43 \%)$ than at the Piedmont (63\%). Most Precordillera burrows showed secondary tunnels, a type of structure absent in the analyzed Piedmont burrows.

Burrows occupied by females had a total length significantly higher $(t=3.89$, $p=0.003$ ) in the Precordillera than in the Piedmont (Table 1), even if the length of secondary tunnels was excluded $(t=3.37, p=0.007)$. Only total length of laterals showed a significantly higher value $(t=6.05, p=0.0001)$, while the differences for the total length of main tunnels $(t=2.01, p=0.08)$ and branches $(t=2.02, p=$ $0.07)$ approached significance. Mean length of laterals was higher at the Precordillera $(t=2.54, p=0.03)$. Numbers of laterals and branches per system $(t=$ $5.14, p=0.0004$ and $t=3.22, p=0.009$, respectively) were significantly higher in Precordillera, although numbers per meter of main tunnel were similar in both environments $(t=0.57, p=0.58$ and $t=1.14, p=0.28$, respectively). Area and perimeter of home range were also significantly higher $(t=2.78, p=0.02$ and $t=$ $2.26, p=0.05$, respectively) in the Precordillera systems, while the linearity indexes did not differ between environments $(t=0.88, p=0.40)$.

Systems occupied by males did not show significant differences in total length $(t=-0.21, p=0.83)$, length of branches $(t=0.55, p=0.59)$ or laterals $(t=1.20$, $p=0.26)$. The main tunnel was somewhat shorter in Precordillera $(t=-1.89, p=$ 0.09 ) and numbers of branches and laterals per meter of tunnel (Table 1) were higher $(U=34.5, p=0.01$ and $t=2.98, p=0.01$, respectively). Burrow system area 
$(U=26, p>0.20)$, perimeter $(t=-1.47, p=0.17)$ and linearity of home range $(t=$ $-0.90, p=0.38$ ) were similar in both environments.

The sexes were grouped for comparisons of angular variables, as burrows of males and females did not differ significantly either in the Precordillera (Table 3) or in the Piedmont (Rosi et al. 1996). The mean directional angle, the angle of ascent of laterals ending in the surface, and the branch angle did not significantly differ between environments (Table 3 ).

\section{Discussion}

\section{Burrow architecture of $C$. mendocinus in the Andean Precordillera}

Burrow systems showed a linear and bifurcated configuration, similar to that described for other subterranean mammals with solitary habits (Jarvis and Sale 1971, Reichman et al. 1982, Andersen 1988, Heth 1989). This pattern is also shared with other species of Ctenomys living in areas with different environmental conditions (Pearson 1959, Antinuchi and Busch 1992).

Differences between sexes in the size of the burrow systems were documented for some subterranean rodents, associated with: (a) different energetic and nutritional requirements derived from the dimorphism in body weight in Spalax ehrenbergi (Heth 1989), and (b) higher excavatory activity carried out by males during the reproductive period in C. mendocinus of the Andean Piedmont (Rosi et al. 1996). The strong sexual dimorphism in size and body weight in C. mendocinus of Precordillera was not reflected in the size and structural features of the burrow systems. Besides, non-significant correlations were found between total length of systems and body weight for males and females. Both results suggest that higher nutritional requirements and reproductive activities expected for males would be resolved through other mechanisms than the lengthening of burrows. Similarity between burrows of males and females despite differences in body weight was also reported for C. talarum (Antinuchi and Busch 1992).

Barely probable seems the hypothesis that evidences of a sexual dimorphism in burrow systems were concealed by the secondary occupation by females of abandoned male burrows and vice versa. In fact, the optimal dispersal theory for subterranean rodents (Nevo 1979) predict that once adults have established their territories, they will remain sedentary through their lives. The analyzed animals in the present study, sexually active adults, differ from the typical dispersers identified for other subterranean rodents as mostly juveniles and subadults (Howard and Childs 1959, Williams and Cameron 1984) or non-reproductive adults (Malizia et al. 1995, Zenuto and Busch 1998).

Precordillera systems seem to have a construction pattern similar to that described for other fossorial rodents (Vleck 1981, Reichman et al. 1982, Andersen 1988), whose systems grow by addition of basic building units. It was impossible to delimit these units of construction in the case of $C$. mendocinus, owing to the high 
variability of the interfork distances. Nevertheless, the lengthening of the main tunnel occurred by adding new segments, and not by the lengthening of segments. The number of branches and laterals increased with the lengthening of the main tunnel, while the mean length of these forks remained constant. The presence of long tunnel sections without laterals accounting for the high variability of interfork distances, could be originated by two mechanisms: (a) the non-construction of new laterals owing to the animal depositing the excavated soil in abandoned tunnels, and (b) the disappearance of laterals due to a progressive compactness of the soil plugging them. Feeding laterals, without a mound, could be confused with old laterals used to transport excavated soil to the surface and could determine interforks shorter than the real one.

The mean directionality close to $0^{\circ}$ and the perpendicular origin of the branches are two geometrical attributes of $C$. mendocinus systems in Precordillera. These structural features would produce an efficient search path according to the predictions from the optimal foraging theory (Pyke 1978), as has been mentioned for other subterranean rodents (Andersen 1988, 1990, Antinuchi and Bush 1992). Mean directional angles close to $0^{\circ}$ can generate a feeding path that does not cross itself and orthogonal branching can maximize the spatial information obtained per unit length of tunnel constructed (Andersen 1988).

C. mendocinus constructed laterals with angles of ascent close to $40^{\circ}$, and few laterals exceeded slopes of $60^{\circ}$. Vleck (1981) proposed for Thomomys bottae that shorter vertical laterals could reduce the cost of digging with respect to longer gently sloping laterals. However, steeper slopes might make soil extraction and the plugging of laterals difficult, because loose soils tend to fall back into the burrow (Hickman 1990). The slope of laterals in C. mendocinus systems is probably determined by the need to plug burrow entrances to minimize the predation risk and to maintain burrow microclimate conditions.

In C. mendocinus burrows, the most secondary tunnels originated a similar structure to the "elementary cycle" mentioned by Airoldi and De Werra (1993) for linear systems of the fossorial Arvicola terrestris. This structure was composed by a secondary tunnel and its corresponding section of the main tunnel. These structures were not as complex as the anastomosing tunnels reported for other subterranean mammals (Airoldi 1981, Hickman 1990). Different factors such as food availability, cost of burrowing, population density and anti-predator defence, among others, may be related to the simplicity or complexity of burrow systems (Airoldi 1981, Heth 1989, Hickman 1990). In C. mendocinus the high percentage of secondary tunnels originating at plants and the presence of branches and laterals along them suggest that these tunnels were mainly constructed as foraging paths.

The positive association of secondary tunnels, laterals and branches with plants located in their origin, together with the low proportion of the main tunnel intersecting plant locations, indicated that animals changed their pattern of search where plants were encountered. A similar pattern has been suggested by Andersen (1988) for Geomys bursarius as consistent with the hypothesis of "area-restricted 
search" (Tinbergen et al. 1967). Other authors considered that this strategy would represent an efficient way to search in environments with plants scarce and clumped (Andersen 1988, 1990, Benedix 1993), as occurs in the analyzed environment of Precordillera.

Areas surrounding C. mendocinus systems showed old signs of burrowing activity and a severe decline in plant cover. These facts suggest that burrow systems are dynamic structures, where exploited places with depleted food are gradually abandoned, and feeding tunnels are extended through places with higher food availability, as was reported for Spalacopus cianus (Contreras et al. 1993). These authors suggest that the continuous expansion of the foraging area abandoning previously exploited areas, might represent an efficient foraging strategy, taking into account that the high cost of burrowing would not compensate the benefits obtained. In G. bursarius the construction of new tunnels was accompanied by mound-building and simultaneous backfilling of older tunnels of the system (Andersen 1987, Thorne and Andersen 1990). A similar burrowing behaviour could be used by $C$. mendocinus, taking into account the presence of plugged tunnels in different sections of the system, and a number of mounds per system strongly lower than the reported for other subterranean mammals (Jarvis and Sale 1971, Hickman 1977, Bandoli 1981, Heth 1989). The deposition of sheared soil into unused tunnels reduces the energetic cost needed to push this soil onto the surface (Vleck 1981), and minimize the predation-risk associated with the mound construction (Sparks and Andersen 1988, Hickman 1990). Reducing exposure on ground surface may be very important for $C$. mendocinus, given the scarce plant cover and the absence of high shrubs and trees that may increase the vulnerability to predation.

\section{Burrow systems in different plant communities}

Differences between Precordillera and Piedmont burrow systems of C. mendocinus are expected, given the lower structural plant complexity, diversity and plant cover in the Precordillera compared with that of the Piedmont. A lower food availability for C. mendocinus would be expected in environments with lower plant abundance and complexity, taking into account that this rodent has been identified as a generalist herbivore in other environment of the Andean Piedmont (Madoery 1993, Puig et al. 1999). These researches revealed that this rodent diet included most plant categories presented (grasses, forbs, succulents and shrubs).

A lower plant cover, especially of shrubs and trees would determine also a greater risk of aerial predation (Rosenzweig 1973, Kotler 1984, Lima and Dill 1990). Aerial predation over subterranean rodents was documented for several species (Howard and Childs 1959, Pearson et al. 1968, Smith 1981, Heth 1991), some of them with frequent above-ground movements (Proulx et al.1995). Longer and more complex systems could be expected in environment with lower shrubs and trees cover, as a strategy to minimize the external movements in order to avoid aerial predation risk. Evidences of above-ground foraging for C. mendocinus (Puig et al. 1992, Rosi et al. 1996) indicate that animals feed from the surface burrows 
opening or near them, besides harvesting plant food from the underground as digging progresses.

Longer and more branched systems have been associated with lower food availability (Jarvis and Sale 1971, Reichman et al. 1982, Antinuchi and Busch 1992). C. mendocinus partially agrees with these predictions, according to each sex: female burrows were larger and male burrows more branched in the Precordillera than in the Piedmont. The greater extension of female systems from the Precordillera compared with those from the Piedmont was due to longer laterals and a higher number of branches and laterals, rather than to a longer main tunnel, or to the presence of secondary tunnels. Male systems from the Precordillera showed a greater number of branches and laterals per tunnel meter than those from the Piedmont, but the system size was similar in both habitats, and there were no differences in the extension of tunnels or in the home range surface. The similar size of male systems from both environments suggests that there are other factors apart from food requirements affecting the extension of these burrow systems. Males searching for females during the reproductive season in the Piedmont was considered a determinant factor to the higher linearity and length in male systems compared with female systems (Rosi et al. 1996). Differences in burrow structure and size among environments could be also influenced by environmental factors as soil structure and composition, slope, rainfall, among others. Further studies could help to distinguish the relative importance of these factors.

The relatively constant heading within main tunnel, orthogonal branching and angles of ascent of laterals close to $40^{\circ}$ are shared by systems of both environments. These geometric attributes identify the construction structure of C. mendocinus systems as efficient search paths, independent of environmental features. Otherwise, systems with a greater length and a more complex structure (a higher branching level) were found in the environment with a lower plant cover, suggesting an adaptive strategy to optimize the foraging efficiency and minimize the predation risk.

Acknowledgements: We are grateful to anonymous reviewers for their thoughtful suggestions and comments on the manuscript. We thank N. Horak and M. E. Soler for the correction of the English version. Financial support was provided by CONICET (Pid 387200/92).

\section{References}

Airoldi J. P. 1981. Nouvelles considèrations sur le terrier du campagnol terrestre (Arvicola terrestris scherman Shaw) (Mammalia, Rodentia): rèsultats prèliminaires. Défense des Végétaux 208: 155-161.

Airoldi J. P. and De Werra D. 1993. The burrow system of the fossorial form of the water vole (Arvicola terrestris scherman Shaw) (Mammalia, Rodentia): an approach using graph theoretical methods and simulation models. Mammalia 57: 423-433.

Ambrosetti J. A., Del Vitto L. A. and Roig F. A. 1986. La vegetación del Paso de Uspallata, Provincia de Mendoza, Argentina. Veröffentlicher Geobotanischen Institutes ETH. Stiftung Rübel (Zürich) 91: 141-180.

Andersen D. C. 1987. Geomys bursarius burrowing patterns: influence of season and food patch structure. Ecology 68: 1306-1318. 
Andersen D. C. 1988. Tunnel construction methods and foraging path of a fossorial herbivore, Geomys bursarius. Journal of Mammalogy 69: 565-582.

Andersen D. C. 1990. Search path for a fossorial herbivore, Geomys bursarius, foraging in structurally complex plant communities. Journal of Mammalogy 71: 177-187.

Antinuchi C. D. and Busch C. 1992. Burrow structure in the subterranean rodent Ctenomys talarum. Zeitschrift für Säugetierkunde 57: 163-168.

Bandoli J. H. 1981. Factors influencing seasonal burrowing activity in the pocket gopher, Thomomys bottae. Journal of Mammalogy 62: 293-303.

Benedix J. H. Jr 1993. Area-restricted search by the plains pocket gopher (Geomys bursarius) in tallgrass prairie habitat. Behavioural Ecology 4: 318-324.

Cameron G. N., Spencer S. R., Eshelman B. D., Williams L. B. and Gregory M. J. 1988. Activity and burrow structure of Attwater's pocket gopher (Geomys attwateri). Journal of Mammalogy 69: 667-677.

Capitanelli R. 1972. Geología, geomorfología, climatología, fitogeografía y zoogeografia de la provincia de Mendoza. Boletín de la Sociedad Argentina de Botánica 13: 15-49.

Clark P. J. and Evans F. C. 1954. Distance to nearest neighbor as a measure of spatial relationships in populations. Ecology 35: 445-453.

Contreras L. C., Gutierrez J. R., Valverde V. and Cox G. W. 1993. Ecological relevance of subterranean herbivorous rodents in semiarid coastal Chile. Revista Chilena de Historia Natural 66: 357-368.

Corte A. E. 1986. Delimitation of geocryogenic (Periglacial) regions and associated geomorphic belts at $33^{\circ}$ E S. L. Andes of Mendoza, Argentina. Biuletyn Peryglacjalny 31: 31-34.

Heth G. 1989. Burrow patterns of the mole rat Spalax ehrenbergi in two soil types (terra-rossa and rendzina) in Mount Carmel, Israel. Journal of Zoology, London 217: 39-56.

Heth G. 1991. Evidence of above ground predation and age determination of the preyed, in subterranean mole rats (Spalax exrenbergi) in Israel. Mammalia 55: 529-542.

Hickman G. C. 1977. Burrow system structure of Pappogeomys castanops (Geomyidae) in Lubbock County, Texas. American Midland Naturalist 97: 50-58.

Hickman G. C. 1990. Adaptiveness of tunnel system features in subterranean mammal burrows. [In: Evolution of subterranean mammals at the organismal and molecular levels. E. Nevo and O. A. Reig, eds]. Alan R. Liss Inc., New York: 185-210.

Howard W. E. and Childs H. E. 1959. Ecology of pocket gophers with emphasis on Thomomys bottae. Mewa Hilgardia 7: 277-354.

Ingles L. L. G. 1952. The ecology of the mountain pocket gopher, Thomomys monticola. Ecology 1: $87-95$.

Jarvis J. U. and Sale J. B. 1971. Burrowing and burrow patterns of East African mole-rats Tachyoryctes, Heliophobius and Heterocephalus. Journal of Zoology, London 163: 451-479.

Kotler B. P. 1984. Risk of predation and the structure of desert rodent communities. Ecology 65: 689-701.

Lima S. L. and Dill L. M. 1990. Behavioural decisions made under the risk of predation: a review and prospectus. Canadian Journal of Zoology 68: 619-640.

Madoery L. 1993. Composición botánica de la dieta del tuco-tuco (Ctenomys mendocinus) en el piedemonte precordillerano. Ecología Austral 3: 49-55.

Malizia A. I., Zenuto R. R. and Busch C. 1995. Demographic and reproductive attributes of dispersers in two populations of the subterranean rodent Ctenomys talarum (tuco-tuco). Canadian Jcurnal of Zoology 73: 732-738.

Nevo E. 1979. Adaptive convergence and divergence of subterranean mammals. Annual Review of Ecology and Systematics 10: 269-308.

Oosting H. J. 1956. The study of plant communities. W. H. Freeman \& Company, San Francisco: $1-440$.

Pearson O. P. 1959. Biology of subterranean rodents, Ctenomys, in Perú. Memorias del Nuseo de Historia Natural "Javier Prado", Lima 9: 1-56. 
Pearson O. P., Binsztein N., Boiry L., Busch C., Di Pace M., Gallopin G., Penchaszadeh P. and Piantanida M. 1968. Estructura social, distribución espacial y composición por edades de una población de tuco-tucos (Ctenomys talarum). Investigaciones Zoológicas Chilenas 13: 47-80.

Proulx G., Badry M. J., Cole P. J., Drescher R. K., Kolenosky A. J. and Pawlina I. M. 1995. Summer above-ground movements of Northern pocket gophers, Thomomys talpoides, in an Alfalfa field. The Canadian Field Naturalist 109: 256-258.

Puig S., Rosi M. I., Videla F. and Roig V. G. 1992. Estudio ecológico del roedor subterráneo Ctenomys mendocinus en la precordillera de Mendoza, Argentina: densidad poblacional y uso del espacio. Revista Chilena de Historia Natural 65: 247-254.

Puig S., Rosi M. I., Cona M. I., Roig V. G. and Monge S. A. 1999. Diet of a Piedmont population of Ctenomys mendocinus (Rodentia, Ctenomyidae): seasonal patterns and variations according sex and relative age. Acta Theriologica 44: 15-27.

Pyke G. H. 1978. Are animals efficient harvesters? Animal Behaviour 26: 241-250.

Reichman O. J and Smith S. C. 1990. Burrows and burrowing behavior by mammals. [In: Current mammalogy 2. H. H. Genoways, ed]. Plenum Press, New York, London: 197-244.

Reichman O. J., Whitham T. G. and Ruffner G. A. 1982. Adaptive geometry of burrows spacing in two pocket gopher populations. Ecology 63: 687-695.

Roig F. 1976. Las comunidades vegetales del Piedemonte de la Precordillera de Mendoza. Ecosur 3: $1-45$.

Rosenzweig M. L. 1973. Habitat selection experiments with a pair of coexisting heteromyid rodent species. Ecology 54: 111-117.

Rosi M. I., Puig S., Videla F., Madoery L. and Roig V. G. 1992. Estudio ecológico del roedor subterráneo Ctenomys mendocinus en la Precordillera de Mendoza, Argentina: ciclo reproductivo y estructura etaria. Revista Chilena de Historia Natural 65: 221-233.

Rosi M. I., Cona M. I., Puig S., Videla F. and Roig V. G. 1996. Size and structure of burrow systems of the fossorial rodent Ctenomys mendocinus in the Piedmont of Mendoza province, Argentina. Zeitschrift für Säugetierkunde 61: 352-364.

Smith H. C. 1981. The distribution of mammals in southeastern Alberta as indicated by the analysis of owl pellets. Blue Jay 39: 230-238.

Sparks D. W. and Andersen D. C. 1988. The relationship between habitat quality and mound building by a fossorial rodent, Geomys bursarius. Journal of Mammalogy 69: 583-587.

Thorne D. H. and Andersen D. C. 1990. Long-term soil-disturbance pattern by a pocket gopher, Geomys bursarius. Journal of Mammalogy 71: 84-89.

Tinbergen N., Impekoven M. and Frank D. 1967. An experiment on spacing out as a defense against predation. Behaviour 28: 307-321.

Vleck D. 1981. Burrow structure and foraging cost in the fossorial rodent, Thomomys bottae. Oecologia 49: 391-396.

Williams L. R. and Cameron G. N. 1984. Demography of dispersal in Attwater's pocket gopher (Geomys attwateri). Journal of Mammalogy 65: 67-75.

Zenuto R. and Busch C. 1998. Population biology of the subterranean rodent Ctenomys australis (Tuco-tuco) in a coastal dunefield in Argentina. Zeitschrift für Säugetierkunde 63: 357-367.

Zar J. H. 1984. Biostatistical analysis. Prentice-Hall, Englewood Cliffs, New Jersey: 1-718. 